\title{
THE INFLUENCE OF INDONESIAN PROSODIC FEATURES ON ENGLISH WORD STRESS PRODUCTION
}

\author{
Rudha Widagsa \\ English Language Education, Faculty of Teacher Training and Education, Universitas PGRI Yogyakarta, \\ Indonesia \\ E-mail: widagsa@upy.ac.id \\ Sri Wiyanah \\ English Language Education, Faculty of Teacher Training and Education, Universitas PGRI Yogyakarta, \\ Indonesia \\ E-mail:wiyanapbi@gmail.com \\ Primasari Wahyuni \\ Indonesian Language Education, Faculty of Teacher Training and Education, Universitas PGRI Yogyakarta, \\ Indonesia \\ E-mail: sariprima87@gmail.com
}

APA Citation: Widagsa, R., Wiyanah, S., \& Wahyuni, P. (2019). The influence of Indonesian prosodic features on English word stress production. English Review: Journal of English Education, 7(2), 7784. doi: $10.25134 /$ erjee.v7i2.1647.

\begin{abstract}
Generally, word stress tends to be ignored and is not considered a serious problem in Indonesian EFL; most teachers only focus on lexical and grammatical aspects of English. In fact, the prosodic features existing in English greatly affect meaning. This research, therefore, is intended to find out how Indonesian Learners of English (ILE) produce the English word stress. The stressed syllables were identified by using the highest pitch in each word. This research involved 20 respondents whose mother tongue is Indonesian. PRAAT software was applied to analyze the recordings, including measuring the pitch of each word. Word stress is indicated by the highest pitch of each word. The lowest pitch indicates weak stress. The result illustrated that ILE produces inappropriate word stress in second language learning. Most of them are not able to distinguish between strong and weak stressed syllables. This is because in their native language, prosodic features, such as word stress, do not prevail. Thus, English word stress production was heavily influenced by Indonesian features of stress. From the 36 words that become the instrument of this research, less than 50\% were pronounced correctly, in most cases, and the highest pitch fell on last syllables. The absence of prosodic features in Indonesian language and limited knowledge on English phonetics drive the
\end{abstract} ILE to pronunciation error.

Keywords: acoustic measurement; Indonesian EFL; phonetics; pronunciation; prosodic features; word stress.

\section{INTRODUCTION}

The "sound of a language", which is primarily transmitted by prosodic features, does not only convey the content of the utterance, but also other important communicative information. It marks the emotional state of the speaker and can have the effect of being calming, detesting, encouraging, warm, cold, intimate or strange. Moreover, individual way of speaking is a key feature of a speaker's personality, an audible "business card".

For these reasons, prosodic features should be taught in the first line when teaching pronunciation. In Indonesia, pronunciation and the other aspects of English phonetics have not been a major concern in English language teaching (ELT). Almost all English teachers get students to study grammar and vocabulary, practice functional dialogue, take part in productive skill activities and become competent in listening and reading. Yet, some of these teachers make little attempt to teach pronunciation in any overt way and only give attention to it in passing (Harmer, 2001).

However, pronunciation is crucial in communication. It helps students to solve serious intelligibility problems. Pronunciation not only makes students aware of different sounds and sound features, but can also improve their ability in using spoken English properly. Understanding spoken English involves more than the ability to pronoun individual words correctly. It also 
involves an ability to hear and produce stress of English words. On the other hand, students of English tend to ignore stress patterns when they learn pronunciation or vocabulary which consequently leads them to serious pronunciation problems, the problem with comprehension and intelligibility.

Communication in spoken English is organized by suprasegmental features. These suprasegmental features are similar to musical signals. Thus, for the purposes of teaching pronunciation, the teacher needs to understand these musical signals work. Kelly (2001) notes suprasegmental features, as the name implies, are features of speech which generally apply to groups of segments or phonemes. The features which are important in spoken English are stress, intonation, and how sounds change in a connected speech which is called the rhythm. The features of these musical signals are usually bound up in the first language. It means that the features are deeply rooted in the minds of students. Thus, it is common for Indonesian students of English to find it difficult when they hear themselves speak with these suprasegmental features of English.

Some features of English prosody nearly always lead to difficulties for language learners: typical melodic contours (e.g. the accomplishing of the final low at the end of utterances), assignment and production of lexical stress, structuring and realization of rhythm. Depending on their first language or prior acquired foreign languages, speakers exhibit different problems with their English L2 prosody (Hirschfeld, 1994).

Looking more closely at that problem, a teacher can help overcome this barrier and other challenges by thinking of the goal of pronunciation instruction not as helping students to sound like native speakers, but as helping them to learn the core elements of spoken English so that they can be easily understood by others. It can be said that the main concern in teaching pronunciation is intelligibility. Clearly, some pronunciation features are more important than others. Pronouncing the word 'water' with /wo:to/ or /wadər/ may not cause a lack of intelligibility and it is less significant rather than stressing words and phrases inappropriately. In the case of intelligibility, students may have their own accent or retain their first language accent. They do not have to sound exactly like an American or a British. Therefore, speaking
English with a native accent, such as Indonesian accent is acceptable.

Although students are allowed to retain their accent when speaking English, they may not be intelligible if they use inappropriate stress in communication. Hence, stress is admittedly crucial in spoken English. Learners have to be able to put the proper stress in English words. Stress is applied in individual words in phrases, and in sentences. Shifting it around in a phrase or a sentence causes change emphasis or meaning. All English words will contain one syllable that has primary stress: a syllable that is more prominent than the other syllables in the word (Meyer, 2002). In the word ladder, for example, the primary stress lies on the first syllable because of the two syllables in this word, the first syllable is more prominent than the second one. Many other variations in stress can be associated with the grammatical structure of the words.

English words with more than one syllable mostly have a fixed stress alternation pattern. There are not many rules to show which syllable of a word will be stressed, learners of English usually have to learn the stress alternations of a word along with its meaning, spelling, and pronunciation. Meanwhile, in Indonesia, stress is considered an unimportant subject to be taught. Correspondingly, students of English in Indonesia barely perceive English word stress alternation. This misunderstanding of stress can cause vital intelligibility problem.

There are previous research related to second language production in accordance with suprasegmental features, one of them is Roosman (2010) who investigated the influence of Indonesian on the production of Dutch word stress. He found that the realization of Dutch stressed vowels by the Indonesian students is probably influenced by the durational structure of their mother tongue. The Indonesian students of Dutch realized stressed vowels with more lengthening than the Dutch native speakers did. This may be because the length is not a distinctive feature in Indonesian; it does not differentiate one vowel from another, as is the case with the lax (short) vowels and their tense (long) counterparts in Dutch.

The other one is Adam (2013). He writes about how prosodic elements have abilities to improve pronunciation in English language learners. $\mathrm{He}$ states that second language pronunciation can improve to be near native-like with the implementation of certain criteria, such 
as the utilization of prosodic elements. With the emphasis on meaningful communication and the understanding that speech production is affected by speech perception, there is a need to integrate prosodic with communicative activities providing situations to develop student pronunciation through listening and speaking. This short overview examines such elements.

However, research on word stress, more specifically in English word stress by English-L2 speakers especially Indonesian students has not been done. Thus, this research intend to investigate the influence of Indonesian prosodic features on English word stress. The research question proposed is how does the Indonesian prosodic feature affect the English word stress?

\section{The nature of stress}

Some languages are said to have fixed stress or to be fixed-stress languages. For example, in Indonesian and Javanese, stress normally found at the last syllable (si'ji, lo'ro, te'lu or sa'tu, $d u^{\prime} a, t i^{\prime} g a$ ). In a general sense, stress is variable in English. If a person still learning English as a new language says beginner instead of be'ginner, those who already know the language consider it a mispronunciation, even though the meaning is probably clear enough. In English, words stress is not fixed - but does that mean that it is not predictable?

Stress in English is produced by; (1) increased activity of the respiratory muscles, producing loudness, as well as by (2) exaggeration of consonant and vowel properties, such as vowel height and stop aspiration, and (3) exaggeration of pitch so that low pitches are lower and high pitches are higher (Ladefoged, 2001). The pitch of a sound itself is an auditory property that enables a listener to place it on a scale going from low to high, without considering its acoustic properties.

English is a language with variable stress rather than fixed stress. Determining syllable can be difficult. English words with more than one syllable mostly have a fixed stress pattern. There are not many rules to show which syllable of a word will be stressed, learner of English usually has to learn the stress pattern of a word along with its meaning, spelling, and pronunciation. Stress also has a function in distinguishing between a noun and a verb or an adjective and an adverb. Many other variations in stress can be associated with the grammatical structure of the words. In English morphological derivation word, there are kinds of alternation in stress that can occur.
It is not easy to define stress from a listener's point of view. A stressed syllable is often but not always, louder than an unstressed syllable. Roach (1991) added that every syllable is said on some pitch; pitch in speech is closely related to the frequency of vibration of the vocal folds and to the musical notion of low and highpitched notes. It is essentially a perceptual characteristic of speech. It means that if one syllable of our "nonsense word" is said with a pitch that is noticeably different from that of the others, this will have a strong tendency to produce the effect of prominence. For example, if all syllables are said with low pitch except for one said with high pitch, the high-pitched syllable will be heard as stressed and the others as unstressed.

\section{METHOD}

To analyze the stress alternation patterns in ILE, the writer randomly chose 20 students from Indonesian Language Education Study Program of University of PGRI Yogyakarta. The twenty students came from different background. Since they are student-teachers, they should be able to pronounce every single English word correctly and manage to convey the actual meaning in conversation.

The object of this research is the highest pitch in each of instrumental words in order to draw the stress patterns produced by the participants. The data were obtained from the recording of participants. The research applies sound wave and pitch diagram. Here, the PRAAT software was used to describe the sound of language then converted to sound wave or pitch.

There were two steps in collecting the data, firstly, the students are asked to listen to the instruments (5 morphological derivation words). Secondly, the students are asked to produce what they exactly heard while the researcher records them one by one. After the listening and recording process is done, the sounds are converted to soundwaves and pitch graphs using PRAAT free software. The soundwaves and pitch graphs are segmented syllable by syllable to analyze the movement of the pitch then the stress pattern can be drawn and seen.

\section{RESULTS AND DISCUSSION}

Every word in English has major stress (primary stress) that is stronger than the others. There are several ways to measure the word stress, such as loudness, syllable length, pitch, and vocal 
quality. This research does not use all of these parameters, only the pitch contours will be used as a reference point of word stress. Here are the instrumental words and the result of the measurement.

Table 1. Instrumental words

\begin{tabular}{|c|c|c|c|c|c|}
\hline $\begin{array}{c}\text { Primary Stress } \\
\text { on First } \\
\text { Syllable }\end{array}$ & $\begin{array}{c}\text { Phonetic } \\
\text { Transcription }\end{array}$ & $\begin{array}{c}\text { Primary } \\
\text { Stress on } \\
\text { Second } \\
\text { Syllable }\end{array}$ & $\begin{array}{c}\text { Phonetic } \\
\text { Transcription }\end{array}$ & $\begin{array}{c}\text { Primary Stress } \\
\text { on the Third } \\
\text { Syllable }\end{array}$ & $\begin{array}{c}\text { Phonetic } \\
\text { Transcription }\end{array}$ \\
\hline Accident & /'aksid(ə)nt/ & Acceptance & /ək'sept(ə)ns/ & Afternoon & /a:fto'nu:n/ \\
\hline Strawberry & /'stro:b(ə)ri/ & Vanilla & /və'nılə/ & Absolute & /'absəlu:t/ \\
\hline Seventy & /'sev(ə)nti/ & Examine & /ıg'zamin/ & Seventeen & /scv(ə)n'ti:n/ \\
\hline Analyse & /'an(ə) $\operatorname{l\Lambda Iz/~}^{\prime}$ & Analysis & /a'nalisis/ & Analytical & /anə'litık(ə)1/ \\
\hline Diplomat & /'dipləmat/ & Diplomacy & /di'pləuməsi/ & Diplomatic & /dıplə'matık \\
\hline Photograph & /'fəutəgra:f/ & Photography & /fa'tpgrəfi// & Photographic & /, fəutə' grafik/ \\
\hline Politic & /'pplitık/ & Politician & /ppli'tIJ(ə)n/ & Political & /pə'litık(ə)1/ \\
\hline Monotone & /'mpnətəun/ & Monotony & /mə'npt(ə)ni/ & Monotonic & /mpnə(ひ)'tpnik/ \\
\hline Yesterday & /'jestədi/ & Tomorrow & /tə' mprəu/ & Recommended & /,rekə'mendid/ \\
\hline President & /'prezId(ə)nt/ & Policeman & /pə'li:smən/ & Guarantee & '/gar(ə)n'ti:/ \\
\hline Salary & /'saləri/ & Employer & /Im' ploıə/ & Employee & /عmploı'i:/ \\
\hline Personal & /'pə:s(ə)n(ə)1/ & Repairman & /ri'pe:mən/ & Personel & /pə:sə'nel/ \\
\hline Translating & /trans' leit/ & Translation & /trans' leI $\int(\partial) \mathrm{n} /$ & Gasoline & /'gasəli:n/ \\
\hline Elephant & /'Elıf(ə)nt/ & Gorilla & /ga'rila/ & Kangaroo & /,kango'ru:/ \\
\hline February & /'februəri/ & December & /di'sembə/ & Overlook & /əuvə'lok/ \\
\hline
\end{tabular}

Looking at Table 1, it is clear that every word in English has specific stress. If the word only consists of one syllable then there is only one primary stress, if the word consists of more than one syllable then there will be major stress (primary stress) and the other syllables have a lower stress level and even none. In this research, the instrumental words consist of three categories of words based on the location of stress, namely the first, second and third syllable.

Unlike English, Indonesian does not have word stress. Indonesian speakers generally do not know the position of word stress in English. The following is the result of taking the data of speakers of Indonesian in pronouncing the English word. In taking the data, 20 respondents in this research first listen to the word to be pronounced. Respondents were asked to listen to native English speakers audiofile then practice the instruments, every instrumental word is inserted in a carrier sentence in order to make it sound more natural.

In the data analysis, the recording of the respondents was analyzed by using PRAAT software to find out the highest pitch position. This position is the reference that word stress falls on a particular syllable where the highest pitch is located.

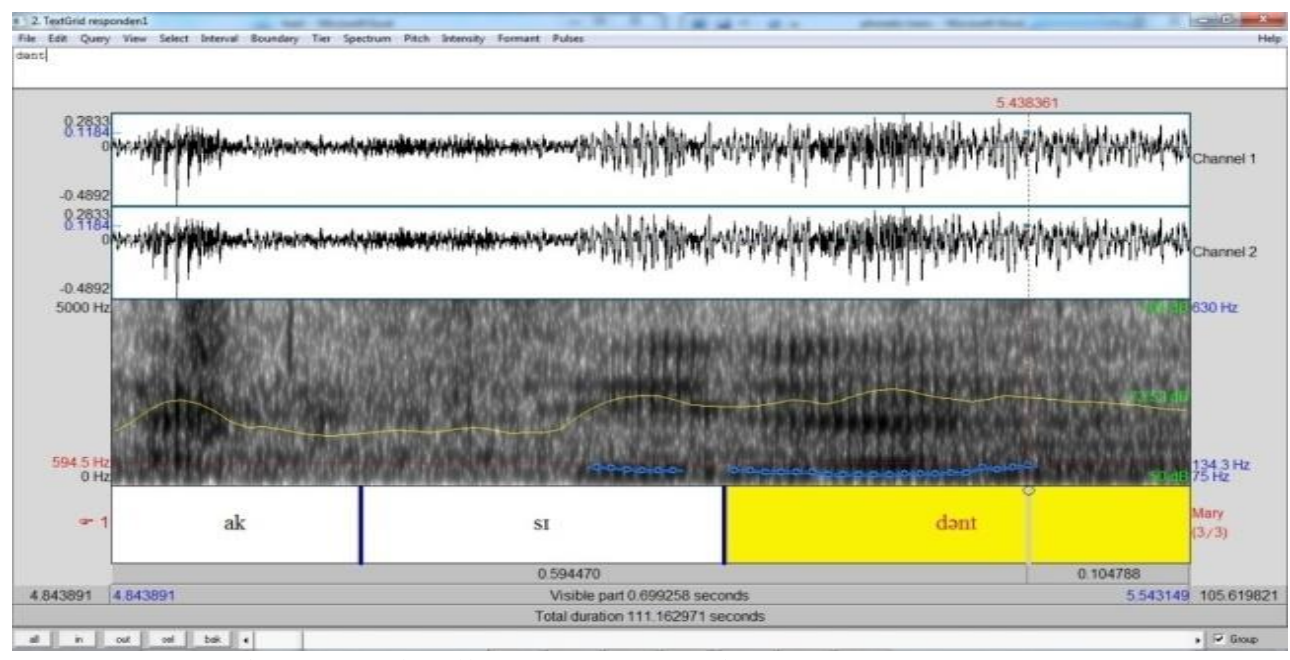

Figure 1. The illustration of pitch contour measurement 
ENGLISH REVIEW: Journal of English Education

Volume 7, Issue 2, June 2019
p-ISSN 2301-7554, e-ISSN 2541-3643

https://journal.uniku.ac.id/index.php/ERJEE
Figure 1 is one example of data retrieval in this research. In Figure 1, the dashed vertical red line is the highest pitch marker of the word 'accident'. The highest pitch lies in the final syllable whereas in English the word 'accident' is a word with the word stress on the first syllable.

Further, the results of data recapitulation of all respondents were presented in three tables.
The first table (Table 2) is a table in which the first syllable gets more stress than the other syllables, the second table (Table 3 ) is the word category with the word stress on the second syllable, and the third table (Table 4) is the word instrument that has the stress of the word on the third syllable.

Table 2. English word stress on first syllable

\begin{tabular}{|c|c|c|c|c|c|c|c|c|c|}
\hline \multirow[t]{2}{*}{ Words } & \multirow{2}{*}{$\begin{array}{l}\text { Number } \\
\text { of } \\
\text { Responde } \\
\text { nts }\end{array}$} & \multirow{2}{*}{$\begin{array}{c}\text { Actual } \\
\text { Data } \\
\text { Recorde } \\
\text { d } \\
\end{array}$} & \multirow[t]{2}{*}{ Correct } & \multirow[t]{2}{*}{ Percentage } & \multicolumn{5}{|c|}{$\begin{array}{c}\text { Variety Of } \\
\text { Stressed Syllables }\end{array}$} \\
\hline & & & & & $1 \mathrm{st}$ & 2 nd & $3 \mathrm{rd}$ & 4 th & 5 th \\
\hline Accident & 20 & 20 & 4 & $20 \%$ & 4 & 7 & 9 & 0 & 0 \\
\hline Strawberry & 20 & 20 & 10 & $50 \%$ & 10 & 0 & 10 & 0 & 0 \\
\hline Seventy & 20 & 20 & 7 & $35 \%$ & 7 & 3 & 10 & 0 & 0 \\
\hline Analyse & 20 & 20 & 2 & $10 \%$ & 2 & 4 & 14 & 0 & 0 \\
\hline Diplomat & 20 & 18 & 7 & $39 \%$ & 7 & 2 & 9 & 0 & 0 \\
\hline Photograph & 20 & 20 & 5 & $25 \%$ & 5 & 8 & 7 & 0 & 0 \\
\hline Politic & 20 & 20 & 5 & $25 \%$ & 5 & 2 & 13 & 0 & 0 \\
\hline Monotone & 20 & 20 & 3 & $15 \%$ & 3 & 2 & 15 & 0 & 0 \\
\hline Yesterday & 20 & 20 & 6 & $30 \%$ & 6 & 5 & 9 & 0 & 0 \\
\hline President & 20 & 20 & 4 & $20 \%$ & 4 & 3 & 13 & 0 & 0 \\
\hline Salary & 20 & 20 & 7 & $35 \%$ & 7 & 1 & 12 & 0 & 0 \\
\hline Personal & 20 & 20 & 4 & $20 \%$ & 4 & 1 & 15 & 0 & 0 \\
\hline Translating & 20 & 20 & 1 & $5 \%$ & 1 & 1 & 18 & 0 & 0 \\
\hline Elephant & 20 & 20 & 0 & $0 \%$ & 0 & 4 & 16 & 0 & 0 \\
\hline February & 20 & 20 & 7 & $35 \%$ & 7 & 6 & 1 & 6 & 0 \\
\hline & & TOTAL & & & $\begin{array}{c}72 \\
24 \%\end{array}$ & $\begin{array}{c}49 \\
16 \%\end{array}$ & $\begin{array}{r}171 \\
57 \%\end{array}$ & $\begin{array}{c}6 \\
2 \%\end{array}$ & $\begin{array}{c}\mathbf{0} \\
0 \%\end{array}$ \\
\hline
\end{tabular}

It can be seen from Table 2 that less than $50 \%$ of respondents say the word instrument with the correct word stress. 57\% word stress falls on the third or last syllable. Only $24 \%$ of respondents put stress on the first syllable. The words 'elephant' and 'translating' occupy the top position where less than two respondents pronounce correctly. In those two words, most respondents put stress on the third syllable.

It can be concluded that more than $75 \%$ of respondents put stress words in the wrong position. In Indonesian, generally the last syllable gets more emphasis than the other syllables (Zanten \& Goedemans, 2009; Zanten \& Heuven, 1998).

In this case, since word stress does not exist in Indonesian phonological system, the speakers tend to ignore the existence of word stress in English phonological system. In other words, the production of English word stress by Indonesian native speakers was greatly influenced by the prosodic system of Indonesian Language. Apart from this, Li, Zhang, Li, Lo, \& Meng (2010) also mentioned that Chinese learners of English produced inappropriate English word stress due to the influence of Chinese prosodic features.

Table 3. English word stress on second syllable

\begin{tabular}{|c|c|c|c|c|c|c|c|c|c|}
\hline \multirow[t]{2}{*}{ Words } & \multirow{2}{*}{$\begin{array}{c}\text { No. of } \\
\text { Responde } \\
\text { nts }\end{array}$} & \multirow{2}{*}{$\begin{array}{c}\text { Actual } \\
\text { Data } \\
\text { Recorde } \\
\text { d }\end{array}$} & \multirow[t]{2}{*}{ Correct } & \multirow[t]{2}{*}{ Percentage } & \multicolumn{5}{|c|}{$\begin{array}{c}\text { Variety of } \\
\text { Stressed Syllables }\end{array}$} \\
\hline & & & & & $1 \mathrm{st}$ & 2 nd & $3 \mathrm{rd}$ & 4 th & 5 th \\
\hline Afternoon & 20 & 20 & 7 & $35 \%$ & 3 & 10 & 7 & 0 & 0 \\
\hline Absolute & 20 & 20 & 8 & $40 \%$ & 5 & 7 & 8 & 0 & 0 \\
\hline Seventeen & 20 & 20 & 5 & $25 \%$ & 10 & 5 & 5 & 0 & 0 \\
\hline Analytical & 20 & 20 & 6 & $30 \%$ & 0 & 2 & 6 & 6 & 6 \\
\hline Diplomatic & 20 & 18 & 1 & $5 \%$ & 7 & 7 & 1 & 3 & 0 \\
\hline
\end{tabular}


Rudha Widagsa, Sri Wiyanah, \& Primasari Wahyuni

The influence of Indonesian prosodic features on English word stress production

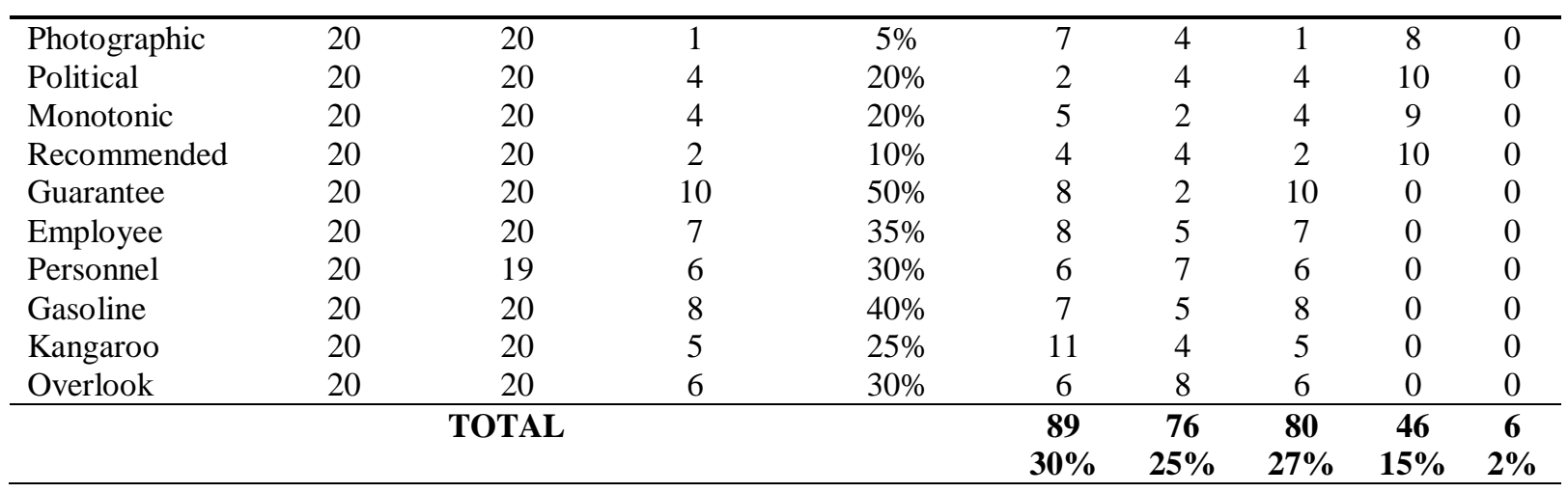

Table 3 shows that the majority of respondents placed word stress on the third syllable with $39 \%$, while the second position occupied by the first syllable with the percentage of $24 \%, 19 \%$ in the second syllable, and $18 \%$ in the fourth syllable. The primary stress is supposed to be in the second syllable. Since most Indonesian words has primary stress on the last syllable, respondents unconsciously make mistakes by placing the word stress on wrong syllables.

Table 4. English word stress on third syllable

\begin{tabular}{|c|c|c|c|c|c|c|c|c|c|}
\hline \multirow[t]{2}{*}{ Words } & \multirow{2}{*}{$\begin{array}{c}\text { Number of } \\
\text { Respondent } \\
\text { s }\end{array}$} & \multirow{2}{*}{$\begin{array}{c}\text { Actual } \\
\text { Data } \\
\text { Recorde } \\
\text { d }\end{array}$} & \multirow[t]{2}{*}{ Correct } & \multirow[t]{2}{*}{ Percentage } & \multicolumn{5}{|c|}{$\begin{array}{c}\text { Variety Of } \\
\text { Stressed Syllables }\end{array}$} \\
\hline & & & & & $1 \mathrm{st}$ & 2nd & $3 \mathrm{rd}$ & 4 th & 5 th \\
\hline Afternoon & 20 & 20 & 7 & $35 \%$ & 3 & 10 & 7 & 0 & 0 \\
\hline Absolute & 20 & 20 & 8 & $40 \%$ & 5 & 7 & 8 & 0 & 0 \\
\hline Seventeen & 20 & 20 & 5 & $25 \%$ & 10 & 5 & 5 & 0 & 0 \\
\hline Analytical & 20 & 20 & 6 & $30 \%$ & 0 & 2 & 6 & 6 & 6 \\
\hline Diplomatic & 20 & 18 & 1 & $5 \%$ & 7 & 7 & 1 & 3 & 0 \\
\hline Photographic & 20 & 20 & 1 & $5 \%$ & 7 & 4 & 1 & 8 & 0 \\
\hline Political & 20 & 20 & 4 & $20 \%$ & 2 & 4 & 4 & 10 & 0 \\
\hline Monotonic & 20 & 20 & 4 & $20 \%$ & 5 & 2 & 4 & 9 & 0 \\
\hline Recommended & 20 & 20 & 2 & $10 \%$ & 4 & 4 & 2 & 10 & 0 \\
\hline Guarantee & 20 & 20 & 10 & $50 \%$ & 8 & 2 & 10 & 0 & 0 \\
\hline Employee & 20 & 20 & 7 & $35 \%$ & 8 & 5 & 7 & 0 & 0 \\
\hline Personnel & 20 & 19 & 6 & $30 \%$ & 6 & 7 & 6 & 0 & 0 \\
\hline Gasoline & 20 & 20 & 8 & $40 \%$ & 7 & 5 & 8 & 0 & 0 \\
\hline Kangaroo & 20 & 20 & 5 & $25 \%$ & 11 & 4 & 5 & 0 & 0 \\
\hline Overlook & 20 & 20 & 6 & $30 \%$ & 6 & 8 & 6 & 0 & 0 \\
\hline \multicolumn{5}{|c|}{ TOTAL } & $\begin{array}{c}89 \\
30 \%\end{array}$ & $\begin{array}{c}76 \\
25 \%\end{array}$ & $\begin{array}{c}80 \\
27 \%\end{array}$ & $\begin{array}{c}46 \\
15 \%\end{array}$ & $\begin{array}{c}6 \\
2 \%\end{array}$ \\
\hline
\end{tabular}

Table 4 surprisingly shows a different result in which the highest percentage of word stress fell in the first syllable instead of the last syllable. However, Indonesian learners of English still put inappropriate stress. It was supposed to be in the third syllable. In this experiment, only $27 \%$ of respondents were correctly put stress on the right syllable. Figure 2 shows the total result of the measurement of English word stress produced by Indonesian learners. 


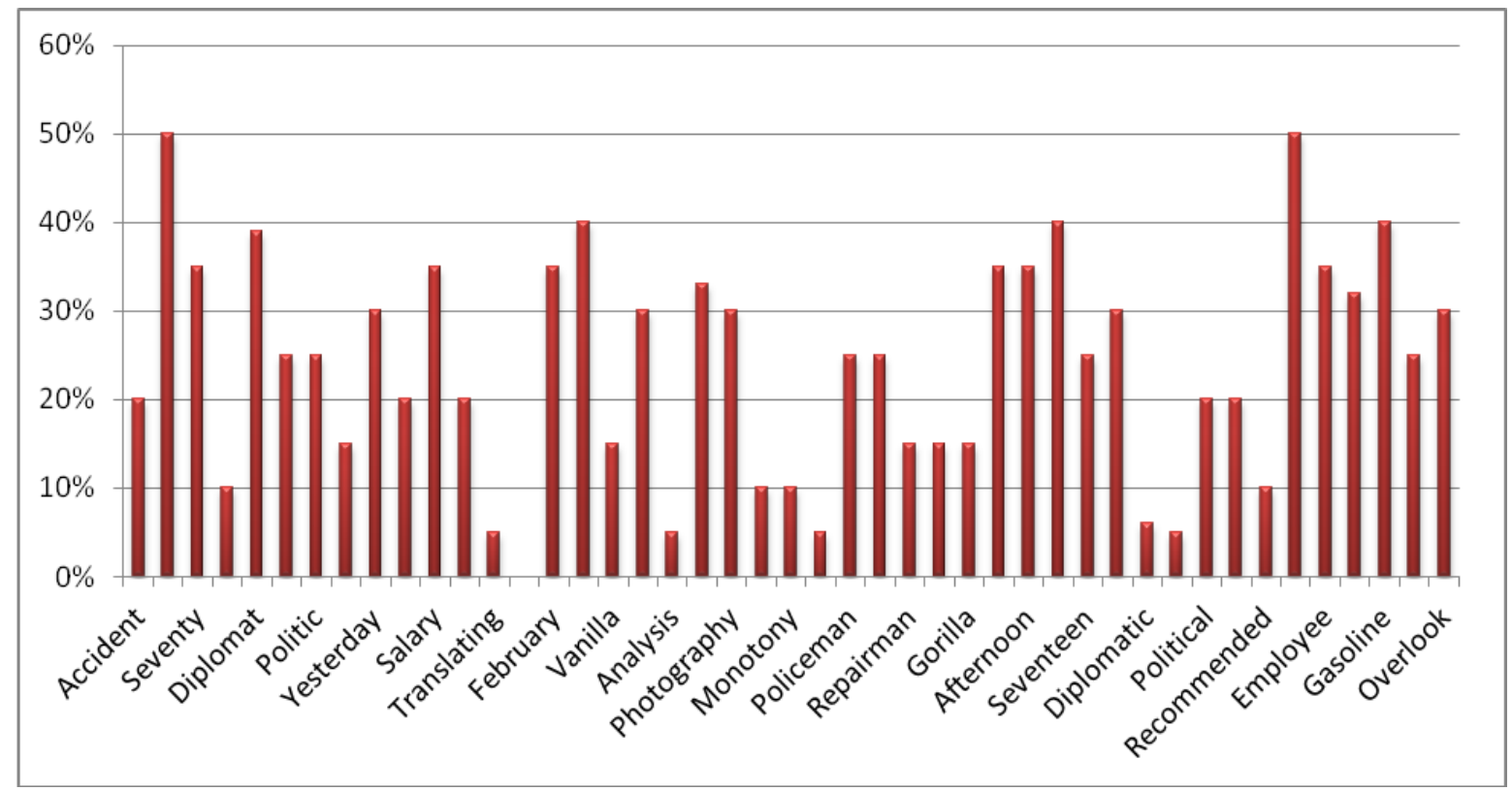

Chart 1. Total result of measurement

The graph shows that most respondents did not pay attention to English word stress. The percentage is not higher than 50 percent. The words 'seventy' and 'employee' occupy the highest number of correct. The word 'employee' has similar characteristics with most Indonesian words, the primary stress falls on the last syllable. On the contrary, the word 'seventy' is also indicated the highest number of correct, yet its stress is on the first syllable. It is because the word 'seventy' is more familiar than the word 'employee'. Indonesian learners used the identical word of 'seventeen' which has similar primary stress.

\section{Influence of Indonesian prosodic system on English word stress}

From the findings, it can be seen that the success of Indonesian speakers in the production of English word stress was very low in which from 36 words that become the instrument of this research, less than $50 \%$ was pronounced correctly. Second language acquisition (SLA) experts argue that the absence of certain phonological features causes an influence on the production of second language pronunciation (Adisasmito-smith, 1999; Munson \& Solomon, 2004; Baker, 2005). In addition, Zanten \& Goedemans (2009) also mentioned that the inexistence of prosodic features in the Indonesian language affected the production of second language acquisition. The absence of prosody in Indonesia causes a negative transfer to learning English since English has prosodic features.
English learning in Indonesia does not consider pronunciation as an important part. The success of learning English is measured from the results of written exams, such as national examinations, the teachers of English do not pay attention to the feature. Furthermore, English is only a subject in schools, it is not used as a tool of communication, the teachers do not even use the language as a medium of instruction in teaching English subject. As a result, pronunciation becomes neglected and it certainly affects the less sensitive English learning outlook with English sounds including the prosodic features in English.

The features of a language as prosodic features that differ from one language and other languages can affect the production of each other (McAllister, Flege, \& Piske, 2002). The error of pronunciation of the word stress spoken by the respondents in this research is caused by the influence of the Indonesian prosodic system which is different from the English language. Indonesian word stress is not a distinguishing feature, while word stress in English is a distinguishing feature (Zanten \& Heuven, 1998).

It can be concluded that the factors that most influence the success of native-like pronunciation are knowledge and awareness about prosodic features in learning English both in the traditional classroom and in the online classroom. Otlowski (1998) also added that the pronunciation of the second language should be taught by being integrated with prosody, communicatively in order that the learner is able to communicate effectively. 
Some EFL experts place more emphasis on learning outcomes in native-like areas, while some other EFL experts like Adams-goertel (2013) emphasized orientation on an understandable approach that develops clear pronunciation styles and easily understood by both native and non-native speakers, native-like is not a primary goal. The "understanding" is also not oriented to the perfection of pronunciation; most of the EFL learning cannot achieve this goal. However, word stress is a crucial feature in English, it determines meaning. Many identical English words which have various meanings are only distinguished by the word stress. This is due to the prosody. Therefore, if English learners do not pay attention to the existing prosodic features in English, it could be a misunderstanding.

\section{CONCLUSION}

From the analysis, it can be concluded that Indonesian speakers do not consider the stress of words in English as an important feature in communication. This is because in the phonology system of Indonesian, prosodic feature is not a distinctive feature. Thus, Indonesian speakers are unaware of the importance of such features in the mastery of spoken English.

This was proved by the error pronunciation of the word instruments in this research. English learners may retain their Indonesian accents when speaking English, but not stress. Error production of stress words will cause misunderstandings in communication. English learners in Indonesia should be able to put English word stress appropriately since such mistakes can lead to shift and change in meaning.

By knowing the production error of speech, the teacher can arrange and develop teaching materials to solve the problem. Therefore, EFL teachers in Indonesia are expected to design and develop proper materials to solve the problem.

\section{ACKNOWLEDGEMENT}

The author would like to thank the Directorate General of Higher Education, Indonesian Ministry of Research, Technology and Higher Education who in partnership with University PGRI Yogyakarta funded this article. Any of the opinions, findings, statements, and conclusions expressed in this article are solely the responsibilities of the author and do not necessarily expose those of the Directorate General of Higher Education.

\section{REFERENCES}

Adams-goertel, R. (2013). Prosodic elements to improve pronunciation in English language learners: A short report. Applied Research on English Language, 2(2), 117-128.

Adisasmito-smith, N. (1999). Influence of Javanese vowel patterning on Indonesian: An acoustic investigation. In 14th International Congress of Phonetic Sciences (ICPhS-14), 14, 1109-1112. Retrieved from https://www.internationalphoneticassociation.or g/icphs-proceedings/ICPhS1999/p14_1109.html

Baker, W. (2005). The interaction of the bilingual's two phonetic systems: Differences in Early and late Korean-English bilinguals. Proceedings of the 4th International Symposium on Bilingualism, 163-174.

Harmer, J. (2001). The practice of English language teaching. Essex: Pearson Education Limited.

Hirschfeld, U. (1994). Untersuchungenzur phonetischen Verständlichkeit Deutschlernender. Frankfurt/M.: Hector.

Ladefoged, P. (2001). A course in phonetics (4th ed.). Texas: Harcourt.

Li, K., Zhang, S., Li, M., Lo, W. K., \& Meng, H. (2010). Detection of intonation in L2 English speech of native Mandarin learners. 7 th International Symposium on Chinese Spoken Language Processing, ISCSLP 2010, 69-74. doi: 10.1109/ISCSLP.2010.5684846.

McAllister, R., Flege, J. E., \& Piske, T. (2002). The influence of L1 on the acquisition of Swedish quantity by native speakers of Spanish, English and Estonian. Journal of Phonetics, 30(2), 229258. doi: 10.1006/jpho.2002.0174.

Munson, B., \& Solomon, N. P. (2004). The effect of phonological neighborhood density on vowel articulation. Journal of Speech, Language, and Hearing Research, 47(5), 1048-1058. doi: 10.1044/1092-4388(2004/078).

Otlowski, M. (1998). Pronunciation: What are the expectations'? The Internet TESL Journal, IV(1). Retrieved from: http://iteslj.org/Articles/OtlowskiPronunciation.html.

Roach, P. (1991). English phonetics and phonology: A practical course. Cambridge: Cambridge University Press.

Zanten, E. V., \& Goedemans, R. (2009). Prominence in Indonesian stress, phrases, and boundaries. Wacana, 11(2), 197-225.

Zanten, E. V., \& Heuven, V. J. V. (1998). Word stress in Indonesian: Its communicative relevance. NUSA, 53, 1-20. 